\title{
Ethnic Chinese Business in Asia
}

History, Culture and Business Enterprise 
This page intentionally left blank

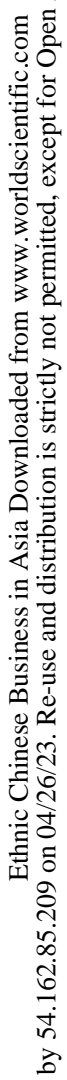




\section{Ethnic Chinese Business in Asia}

History, Culture and Business Enterprise

\section{Ching-hwang Yen \\ The University of Adelaide, Australia}


Published by

World Scientific Publishing Co. Pte. Ltd.

5 Toh Tuck Link, Singapore 596224

USA office: 27 Warren Street, Suite 401-402, Hackensack, NJ 07601

UK office: 57 Shelton Street, Covent Garden, London WC2H 9HE

\section{Library of Congress Cataloging-in-Publication Data}

Yan, Qinghuang, author.

Ethnic Chinese business in Asia : history, culture and business enterprise / Yen Ching-hwang,

University of Adelaide, Australia.

pages $\mathrm{cm}$

Includes bibliographical references and index.

ISBN 978-9814317528 (alk. paper)

1. Corporations, Chinese--Asia. 2. Chinese--Asia--Economic conditions. 3. Business networks--China. 4. Business networks--Asia. 5. International business enterprises--China. 6. International business enterprises--Asia. 7. Entrepreneurship--China. 8. Entrepreneurship-Asia. I. Title.

HD2891.85.Y36 2013

338.7089 '95105--dc23

2013028180

\section{British Library Cataloguing-in-Publication Data}

A catalogue record for this book is available from the British Library.

Copyright $\odot 2014$ by World Scientific Publishing Co. Pte. Ltd.

All rights reserved. This book, or parts thereof, may not be reproduced in any form or by any means, electronic or mechanical, including photocopying, recording or any information storage and retrieval system now known or to be invented, without written permission from the Publisher.

For photocopying of material in this volume, please pay a copying fee through the Copyright Clearance Center, Inc., 222 Rosewood Drive, Danvers, MA 01923, USA. In this case permission to photocopy is not required from the publisher.

In-house Editor: Zheng Danjun

Typeset by Stallion Press

Email: enquiries@stallionpress.com 


\section{Preface}

This book represents a major shift of my research interest from political history, such as Yen Ching-Hwang, The Overseas Chinese and the 1911 Revolution (Kuala Lumpur, Oxford University Press , 1976), to diplomat history, such as Yen Ching-Hwang, Coolies and Mandarins (Singapore, Singapore University Press, 1985) to social history, such as Yen Ching-hwang, A Social History of the Chinese in Singapore and Malaya, 1800-1911 (Singapore, Oxford University Press, 1986) and then to business history and management. This shift of interest began in 1989 when I was attached to the History Department of the University of Hong Kong. The early result of that shift was the publication of a long article titled "The Wing On Company in Hong Kong and Shanghai: A Case Study of Modern Overseas Chinese Enterprise, 1907-1949", first published in Proceedings of Conference on Eighty Year's History of the Republic of China, 1912-1991 (Taipei, 1991), Vol.IV, English Section, pp.77-117, then was re-published in Yen Ching-hwang, Studies in Modern Overseas Chinese History (Singapore, Times Academic Press, 1995), pp.196-236.

This book is partly based on the lectures given at my semester course entitled "Enter the Dragon: Ethnic Chinese Business in Asia" which was taught as a history subject at the University of Adelaide from 1996 to 2001. But the course attracted more students from commerce, economics, law and other disciplines in Arts Faculty as well as international students. The course was the first of its kind taught in Australian universities. The principal aim was to help Australian students to understand Ethnic Chinese Business in Asia. The lectures of this course have been extensively revised and they form about a quarter of this book.

The idea of writing a book combining history, culture, economics and management is intended to provide in-depth knowledge of 
history and culture that have affected the business organisations and behaviour of the Ethnic Chinese. Prevailing works on Chinese business which are mostly written by economists, management experts and sociologists lack of historical and cultural depth that would not have explained Chinese business behaviour and organisations satisfactorily.

I would like to take this opportunity to thank my wife, Mrs. Kwee Ying Yen, for her support and encouragement without which this work might not have been sustained to its eventual publication.

Yen Ching-hwang (Ching-hwang Yen or Yen Ching Hwang) School of History and Politics The University of Adelaide, Australia

9 July 2013 


\section{Contents}

Preface $\quad$ v

Part I History and Culture of Ethnic Chinese Business 1

Chapter 1 Introduction 3

The Scope of Study and the Definition of Ethnic Chinese

Ethnic Chinese Business and Rapid Economic Development in East and Southeast Asia 5

The Rise of Ethnic Chinese Business in Asia $\quad 10$

Chapter 2 The Making of Ethnic Chinese Communities 11

Chinese Emigration 11

Social Structure and Social Mobility in Ethnic

Chinese Communities

Culture and Tradition in Ethnic Chinese

Communities

Chapter 3 Historical Roots of Ethnic Chinese Business

Role and Status of Businessmen in Traditional Chinese Society

Traditional Chinese Business Organizations

Role and Status of Businessmen in Ethnic

Chinese Communities

Traditional Ethnic Chinese Business

Organizations 
viii Ethnic Chinese Business in Asia

Chapter 4 The Rise of Modern Ethnic Chinese Business Enterprise

The Rise of Modern Ethnic Chinese Business Enterprise

The Development of Modern Ethnic Chinese Business Enterprise

The Ideology of Modern Ethnic Chinese

Business Enterprise

The Structure of Modern Ethnic Chinese

Business Enterprise

\section{Part II Structure and Functions of Ethnic}

Chinese Business

Chapter 5 Ethnic Chinese Family Business and

Business Conglomerates

Ethnic Chinese Family Business

Ethnic Chinese Business Conglomerates

Chapter 6 Xinyong (Trust), Guanxi (Relationship), Business Networks and Ethnic Chinese Business

Xinyong and Ethnic Chinese Business

Guanxi, Business Networks and Ethnic Chinese Business

Importance of Business Networks and Business Groups

The Role of Business Networking and the Globalization of Ethnic Chinese Business

Chapter 7 Ethnic Chinese Businessmen and Entrepreneurs

Ethnic Chinese Businessmen

Ethnic Chinese Entrepreneurs and Entrepreneurship 
Chapter 8 Ethnic Chinese Business Management

Confucianism and Traditional Chinese Business Management

Modern Ethnic Chinese Business Management

Contemporary Ethnic Chinese Business

Management

\section{Part III Regional Studies}

Chapter 9 Chinese Business in Thailand

Coastal Trade and Early Chinese Business

The Rise of Modern Chinese Business Enterprise (1851-1942)

Case Studies: Chen Cihong and Khaw Soo Cheang Families

The Rise of Chinese Business Conglomerates

Case Study: Bangkok Bank Group

Chapter 10 Chinese Business in Singapore and Malaysia

Entrepot Trade, Middlemen and Chinese Business

Case Studies: Seah Eu Chin and Tan Kim Seng

Commercial Agriculture, Tin-Mining and Revenue Farming

Case Studies: Tan Hiok Nee and Yap Ah Loy

Chinese and the Rise of Rubber

The Rise of Modern Ethnic Chinese Banking and Manufacturing Industry

Case Studies: Wong Ah Fook and Tan Kah Kee

The Development and Growth of Chinese

Business in Malaysia Since 1957

The Development and Growth of Chinese

Business in Singapore Since 1959 
$\mathbf{x}$ Ethnic Chinese Business in Asia

Chapter 11 Chinese Business in Indonesia 341

Entrepot Trade and Chinese Business 341

The Rise of Modern Chinese Business and Businessmen 346

Case Studies: Oei Tiong Ham and Zhang (Tjong) Brothers 349

Chinese Business in Transition (1907-1965) 360

The Rise of Chinese Business Conglomerates 366

Case Study: Liem Sioe Liong and His Salim Group of Companies

Chapter 12 Chinese Business in the Philippines 379

International Trade and Chinese Business $\quad 379$

Evolution of Modern Chinese Business $\quad 389$

Economic Change and the Rise of Chinese

Business Conglomerates 404

Case Studies: Lucio Tan Group and Yuchengco Group of Companies

Chapter 13 Chinese Business in Hong Kong

Trade and the Chinese Business

The Rise of Modern Chinese Enterprise in Hong Kong

The Rise of the Chinese Textile Industry During the Post-war Era

The Transformation of Hong Kong's Economy and the Chinese Business (1950-1990) 436

Sino-Western Business Relations in Hong Kong 441

Case Studies: Li Ka-shing and Henry Fok Ying Tung 
Chapter 14 Chinese Business in Taiwan 455

Chinese Business in Taiwan Before $1895 \quad 455$

Chinese Business under Japanese Rule and the Post World War II Period 466

The Rise of Taiwan as an Economic Power $\quad 475$

Entrepreneurship, Confucian Values and Taiwan's Business

483

Case Studies: Wang Yung-ching and Chang Yung-fa

Index 